\begin{tabular}{l|c|c}
\hline ISSN: 0001-5113 & ACTA ADRIAT., & ORIGINAL SCIENTIFIC PAPER \\
AADRAY & $62(2): 171-182,2021$ & \\
\hline
\end{tabular}

\title{
Biometry of the sagittal otoliths for three demersal fish species from the Eastern Adriatic Sea (Montenegro)
}

\author{
Dragana MILOŠEVIĆ ${ }^{1}$, Ana PEŠIĆ²*, Zdravko IKICA², Tamara MITROVIĆ ${ }^{2}$ and \\ Nikola PASKA $\breve{S}^{2}$ \\ ${ }^{1}$ University of Montenegro, Faculty of Natural Science and Mathematics, \\ Department of Biology, Podgorica \\ ${ }^{2}$ University of Montenegro ispred Institute of Marine Biology, Kotor, Montenegro \\ *Corresponding author, e-mail: pesica@ucg.ac.me
}

The otolith morphology, biometry and otolith size and fish length relationship of three demersal fish species: red mullet Mullus barbatus, common pandora Pagellus erythrinus and hake Merluccius merluccius were examined. Based on otoliths relative sizes $\mathrm{P}$. erythrinus and M. merluccius have Large otoliths, while M. barbatus has Small sagittal otoliths. The relationships between otolith variables and fish somatic growth were described by a linear function. All relationships were statistically highly significant $(p<0.001)$. Otolith length $(O L)$ was found to be the variable most strongly related to fish size, with $61.2-95.3 \%$ of the variability, while otolith weight had the lowest coefficient of determination $\left(r^{2}\right)$. No differences were found neither between left and right otoliths, nor between male and female otoliths in these relationships. For all species studied the relationships of otolith length, height and weight against total fish length were all found to have positive allometry, indicating that the accretion of otoliths is relatively faster than increase in fish body size. The shape indices of form factor $\left(F_{F}\right)$, roundness $\left(R_{D}\right)$, aspect ratio $\left(A_{R}\right)$, circularity $(C)$, rectangularity $(R)$ and ellipticity $(E)$ were calculated and the relationships between otolith length $(O L)$ and shape indices were determined.

Key words: somatic growth; sagittal otolith; shape and size of otolith; hake; red mullet; common pandora

\section{INTRODUCTION}

Marine demersal resources are represented by fish and other marine organisms that live or feed on or near the sea bottom. The European hake (Merluccius merluccius) and red mullet (Mullus barbatus), along with deep-water pink shrimp (Parapenaeus longirostris), represent main target species both in Montenegrin demersal fish- ery (IKICA et al., 2018; JOKSIMOVIĆ et al., 2019) and in the rest of Adriatic (UNEP-MAP-RAC/SPA 2015). Common Pandora (Pagellus erythrinus) is not the main target species in Montenegrin fisheries, but is one of the "main commercial species" in Montenegro, meaning that it is counted in the group of species representing $90 \%$ in weight of total landing in the country (GFCM, 2018). All three species studied fall into this category, due 
to their importance to the Montenegrin fisheries in terms of quantities and economic value, and are subject to sampling in the frame of the Annual Montenegro fishery data collection programme (DCF-DCRF) according to the GFCM DCRF methodology. The total landing of European hake in Montenegro increases sligthly each year with 47 tons in 2018 (20 tons in 2016, 36 tons in 2017). The situation is similar with red mullet, with a total catch of 42 tons in 2018 (15 tons in 2016, 36 tons in 2017), while the landing of common pandora was estimated at 5 tons in 2018 (Monstat 2019). Despite the high commercial importance of these species in Montenegro, they were not a research subject in previous studies. Available data refer to the length-weight relationships (JOKSIMOVIĆ, 1999; JOKSIMOVIĆ et al., 2007; DULČIĆ \& KRALJEVIĆ, 1996; DULČIĆ \& GLAMUZINA, 2006), growth parameters estimation (JOKSIMOVIĆ, 2001; JOKSIMOVIĆ et al., 2007; 2008; CARBONARA et al., 2018) and populations characteristics (JOKSIMOVIĆ, 2000; MANDIĆ et al., 2008; JOKSIMOVIĆ et al., 2004; PEŠIĆ et al., 2011; PICCINETTI et al., 2021; ZORICA et al., 2020; VRGOČ et al, 2004; VRGOČ et al., 2005).

The otoliths are one of the main biomineral structures of the internal ear in fish, and play a role in balance and hearing. They serve as a permanent record of the life history of individual (BELCHIER et al., 2004). The sagittas are the largest pair of otoliths in most bony fishes (PAXTON, 2000). The size, shape and otolith characteristics vary between species, and the otolith morphology can differ between populations of the same species in different locations (REICHENBACHER et al., 2009; OZPICAK et al., 2018). The morphology of otolith is influenced by ontogenetic development (CAPPOCIONI et al., 2011), size (HÜSSY, 2008, LOMBARTE \& CRUZ 2007), sexual maturation (MÉRIGOT et al., 2007), sex (BOLLES \& BEGG, 2000) as well as diet (MILLE et al., 2016). Environmental factors, such as water temperature, can also produce otolith growth variation, and therefore shape variability (CARDINALE et al., 2004; LOMBARTE \& CRUZ, 2007)

Otolith morphology is considered to be an efficient tool for fish species determination and differentiation between different fish stocks or populations when comparative genetic data are not available (ZHUANG et al., 2014; BOSTANCI et al., 2015), in ecomophological studies (AGUIRRE \& LOMBARTE, 1999; CAPPOCIONI et al., 2011, CARDINALE et al., 2004), and they can serve as an index for environmental studies (DEHGHANI et al., 2015). With the development of image analysis system, the studies of otolith morphology have become increasingly more important in numerous ichthyological studies. Only two studies regarding the morphology and shape contour of fish species from Adriatic Sea have been conducted so far, and were related to pelagic (ZORICA et al., 2010) and juvenile fish species (FERRI et al., 2018). However, until now little information was available on demersal fish species otoliths from Montenegrin waters (South-Eastern Adriatic), and the aim of this study was to analyse the relationship of morphometric measurements of three demersal fish species and their otolith shape variations in order to determine the possible patterns between body size and otolith morphology. The other purpose of this study was to estimate the biometric relationship between fish body measurements and otolith measurements for the selected species and determine which measurements are intercorrelated.

\section{MATERIAL AND METHODS}

\section{Study area}

Eastern Adriatic is characterized by a relatively narrow continental shelf and a steep slope, reaching maximum depth of $1,233 \mathrm{~m}$ (TEŠIĆ, 1962). The total length of Montenegrin coast is $294 \mathrm{~km}, 112 \mathrm{~km}$ of which represents the coast of Boka Kotorska Bay and $182 \mathrm{~km}$ face the open sea. A large part of Montenegrin coastline consists of precipitous rocky cliffs intersected with beaches that become more prevalent towards the south, culminating in a long stretch of sandy beach (Velika plaža in Ulcinj, $13 \mathrm{~km}$ in length, the longest Montenegrin beach) extending to the Albanian border at the mouth of the Bojana River. The total surface area of internal waters is $362 \mathrm{~km}^{2}$, while the surface of territorial waters is 2,098.9 $\mathrm{km}^{2}$ (Fig. 1). 


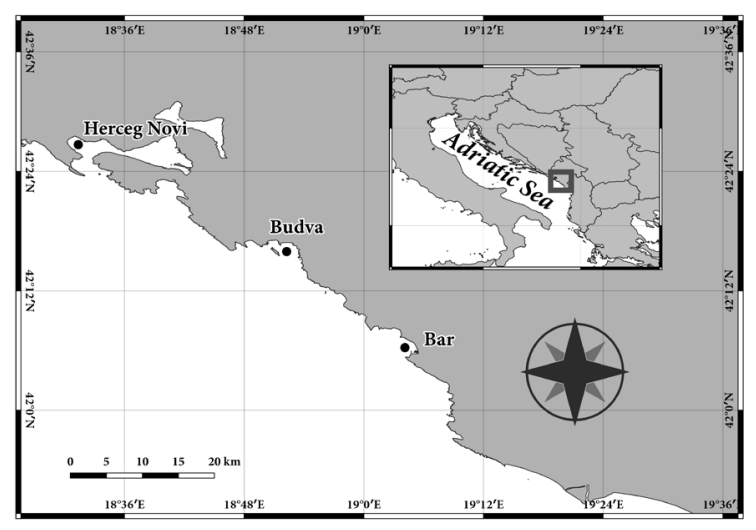

Fig. 1. Map of the study area

\section{Sample collection}

Otoliths of three demersal fish species, $M$. barbatus, $P$. erythrinus and $M$. merluccius, originating from the Montenegrin waters, were examined. The data was collected within the frame of Data Collection Reference Framework (DCRF) programme (GFCM, 2018) performed in Montenegro since 2017 through support by Ministry of Agriculture and Rural Development (DCF-DCRF, 2020). Within the DCRF, several fishing fleet segments are sampled on a quarterly basis, among them segments using demersal trawl nets, fixed nets, i.e. gillnets and trammel-nets (DCF-DCRF, 2020). Samples were collected during direct on-board observation. Total catch of each species was weighted, and subsamples collected for further laboratory analysis. Length of individuals was measured to the nearest $0.1 \mathrm{~cm}$, and weight of individuals measured to the nearest $0.01 \mathrm{~g}$. Specimens were dissected to determine their sex and remove the otoliths. Sagittal otoliths were extracted under a NIKON stereomicroscope, under 50× magnification, and washed in distilled water. After drying the otoliths with filter paper, each otolith was placed on a microscopic plate, with the convex side facing up and measured to the nearest $0.001 \mathrm{~mm}$ under Carl Zeiss Axio Scope A1 microscope and computer-connected camera system. Four morphometric characteristics were measured: the otolith length $(\mathrm{OL}, \mathrm{mm})$, otolith width $(\mathrm{OW}, \mathrm{mm})$, otolith area $\left(\mathrm{A}, \mathrm{mm}^{2}\right)$ and otolith perimeter $(\mathrm{P}, \mathrm{mm})$. These measurements allowed the six shape indices to be calculated: form factor $\left(\mathrm{F}_{\mathrm{F}}\right)$, roundness $\left(\mathrm{R}_{\mathrm{D}}\right)$, aspect ratio $\left(A_{R}\right)$, circularity $(C)$, rectangularity $(R)$, and ellipticity (E) (TUSET et al., 2003; LORD et al., 2012). The $F_{F}$ is the inverse ratio of the squared perimeter of a circle of the same surface; $R_{D}$ is the ratio between the actual area and the area of the circle of the same length while $A_{R}$ is the ratio between the otolith length and otolith width (ZORICA et al., 2010). The otolith weight (OW) was recorded by Mettler Toledo XPE206 analytic balance to the nearest $0.01 \mathrm{mg}$. For all measurements, descriptive statistics (mean, standard error and minimal and maximal values) were calculated. The relationships between otolith measurements (length, height and weight) and fish body lengths were estimated using the linear regression model applied the method of least squares (SOKAL \& ROHLF, 1981). All otolith shape indices were first analysed for normality with Kolmogorov-Smirnov and Shapiro-Wilk tests. Analysis of variance (ANOVA) was used to compare indices between analysed species. Tukey HSD post-hoc test was used to explore differences between multiple group means in cases when ANOVA showed statistically significant differences. Moreover, relationships between shape indices and sagittal otolith length were evaluated. The strength of each relationship was evaluated from the determination coefficient $\left(r^{2}\right)$. The otolith relative size value of each species was calculated using the index $\mathrm{O}_{\mathrm{R}}=1000$ $\times \mathrm{OL} \times \mathrm{TL}^{-2}$. According to $\mathrm{O}_{\mathrm{R}}$, otoliths were grouped into four categories: very small $\left(\mathrm{O}_{\mathrm{R}}<\right.$ 0.10), small (0.10-0.32), medium (0.33-065) and large $(>0.65)$ (LOMBARTE \& CRUZ, 2007). The statistical procedure was completed using SPSS Statistics 20 and STATISTICA 7.0.

\section{RESULTS}

The sagittal otoliths of $M$. merluccius (35.71\% female, $64.28 \%$ male), M. barbatus (70\% female and 30\% male) and P. erythrinus (68.08\% female and $46.87 \%$ male) were evaluated. Table 1 shows a number of individuals studied and their length and weight distribution. There were no statistically significant differences found between left and right otoliths 
Table 1. Sample size (N), total length (TL) and weight (W) range of three demersal fish species used in this study

\begin{tabular}{lllll}
\hline Species & Common name & N & TL range (cm) & W range (gr) \\
\hline Merluccius merluccius & Hake & 56 & $14.5-32.3$ & $17.35-216.32$ \\
Mullus barbatus & Red mullet & 50 & $11.5-20.5$ & $16.25-99.24$ \\
Pagellus erythrinus & Common pandora & 47 & $14.0-25.7$ & $30.37-196.52$ \\
\hline
\end{tabular}

Table 2. Descriptive statistics of morphometric characteristics of sagittal otoliths of three demersal fish species form Montenegro. Shown are mean value and standard error for maximum otolith length - OL, otolith width - OH, otolith weight $-O W$, area $-A$ and perimeter $-P$

\begin{tabular}{llllll}
\hline Species & $\mathrm{OL}(\mathrm{mm})$ & $\mathrm{OH}(\mathrm{mm})$ & $\mathrm{OW}(\mathrm{gr})$ & $\mathrm{A}\left(\mathrm{mm}^{2}\right)$ & $\mathrm{P}(\mathrm{mm})$ \\
\hline Merluccius merluccius & $12.05 \pm 1.89$ & $5.13 \pm 0.76$ & $0.071 \pm 0.028$ & $42.36 \pm 12.51$ & $30.48 \pm 4.53$ \\
Mullus barbatus & $3.07 \pm 0.36$ & $2.27 \pm 0.27$ & $0.033 \pm 0.001$ & $4.78 \pm 0.98$ & $9.34 \pm 1.21$ \\
Pagellus erythrinus & $7.88 \pm 1.27$ & $5.76 \pm 0.88$ & $0.089 \pm 0.042$ & $29.46 \pm 1.93$ & $22.50 \pm 3.59$ \\
\hline
\end{tabular}

Table 3. Regression parameters of the relationship between otolith dimensions and the total body length of three demersal fish species from Montenegro. TL-total body length, OL-otolith length, OH-otolith height, OW-otolith weight, $r^{2}$-correlation coefficient, $p$-level of significance

\begin{tabular}{lllll}
\hline Species & Relationship & Regression equation & $\mathrm{r}^{2}$ & $\mathrm{p}$ \\
\hline \multirow{3}{*}{ Merluccius merluccius } & OL/TL & $\mathrm{OL}=1.1406+0.0457 \mathrm{TL}$ & 0.9531 & $\mathrm{P}<0.001^{* * *}$ \\
& OH/TL & $\mathrm{OH}=0.8022+0.0181 \mathrm{TL}$ & 0.9298 & $\mathrm{P}<0.001^{* * *}$ \\
& OW/TL & $\mathrm{OW}=-0.0902+0.0007 \mathrm{TL}$ & 0.9084 & $\mathrm{P}<0.001^{* * *}$ \\
& $\mathrm{OL} / \mathrm{TL}$ & $\mathrm{OL}=1.133+0.0126 \mathrm{TL}$ & 0.7099 & $\mathrm{P}<0.001^{* * *}$ \\
Mullus barbatus & $\mathrm{OH} / \mathrm{TL}$ & $\mathrm{OH}=0.827+0.0094 \mathrm{TL}$ & 0.6823 & $\mathrm{P}<0.001^{* * *}$ \\
& $\mathrm{OW} / \mathrm{TL}$ & $\mathrm{OW}=-0.0284+0.0003 \mathrm{TL}$ & 0.6121 & $\mathrm{P}<0.001^{* * *}$ \\
\multirow{3}{*}{ Pagellus erythrinus } & $\mathrm{OL} / \mathrm{TL}$ & $\mathrm{OL}=0.604+0.039 \mathrm{TL}$ & 0.8846 & $\mathrm{P}<0.001^{* * *}$ \\
& $\mathrm{OH} / \mathrm{TL}$ & $\mathrm{OH}=0.851+0.026 \mathrm{TL}$ & 0.8393 & $\mathrm{P}<0.001^{* * *}$ \\
& $\mathrm{OW} / \mathrm{TL}$ & $\mathrm{OW}=-0.146+0.001 \mathrm{TL}$ & 0.8429 & $\mathrm{P}<0.001^{* * *}$ \\
\hline
\end{tabular}

( $>0.05)$, or between otoliths of males and females $(p>0.05)$. All otoliths morphometric measurements for the species studied are given in Table 2. Otoliths of $M$. barbatus had the smallest values of all observed parameters, while the otoliths of $M$. merluccius were the largest and with the highest otolith extent area (Table 2). The otolith relative size $\left(\mathrm{O}_{R}\right)$ ranged between 0.21-0.84. According to $\mathrm{O}_{R}$ size categories defined in the methodology, M. barbatus are considered to have Small otoliths, while $M$. merluccius and P. erythrinus have Large otoliths (Table 4). The otolith length, weight and height were linearly related to total fish length for the studied species. Their regression parameters were highly significant $(p<0.001)$. The best fit for all three fish species were for the TL-OL relationships, but some differences were also noticed. Namely, all otolith-fish body biometric relationships (i.e. TL-OL, TL-OH, TL-OW) had high values for M. merluccius and P. erythrinus. The lowest values of coefficient of determination for all examined biometric relationships were found for M. barbatus (Table 3).

According to the mean values of six examined shape indices the otoliths of $M$. merluccius had the smallest values of $F_{F}$ and $R_{D}$ while the values of $A_{R}, C$ and $E$ were the highest. P. erythrinus has the highest value of $\mathrm{F}_{\mathrm{F}}$ indicating flattest edges compared to other species, while $M$. merluccius has the most uneven edges. The otoliths of M. merluccius were the most elongated while the otolith of $M$. barbatus was the most rounded among the examined demersal fish spe- 


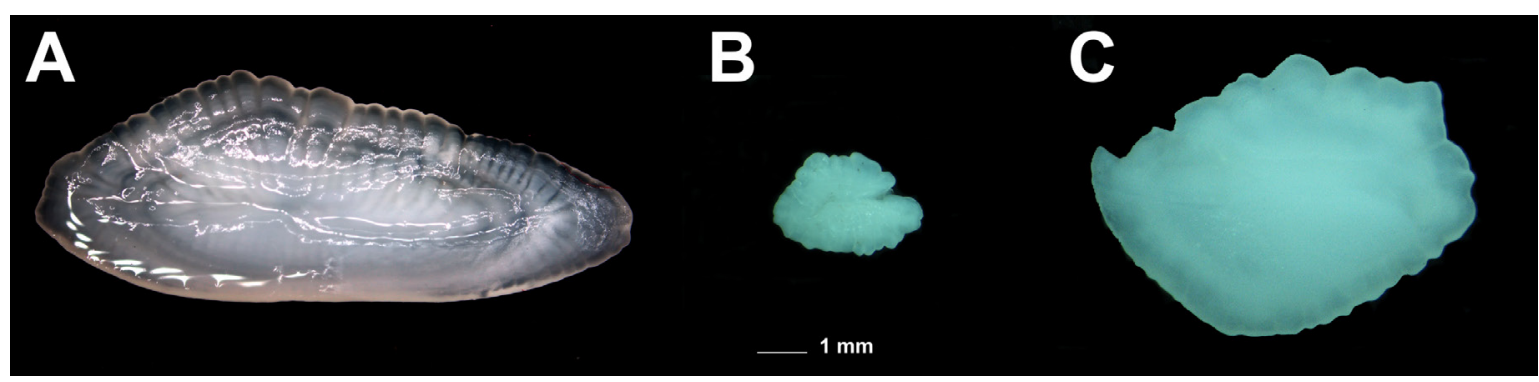

Fig. 2. Images of the saggita of three demersal fish species: A- M. merluccius; B - P. erythrinus C - M.barbatus

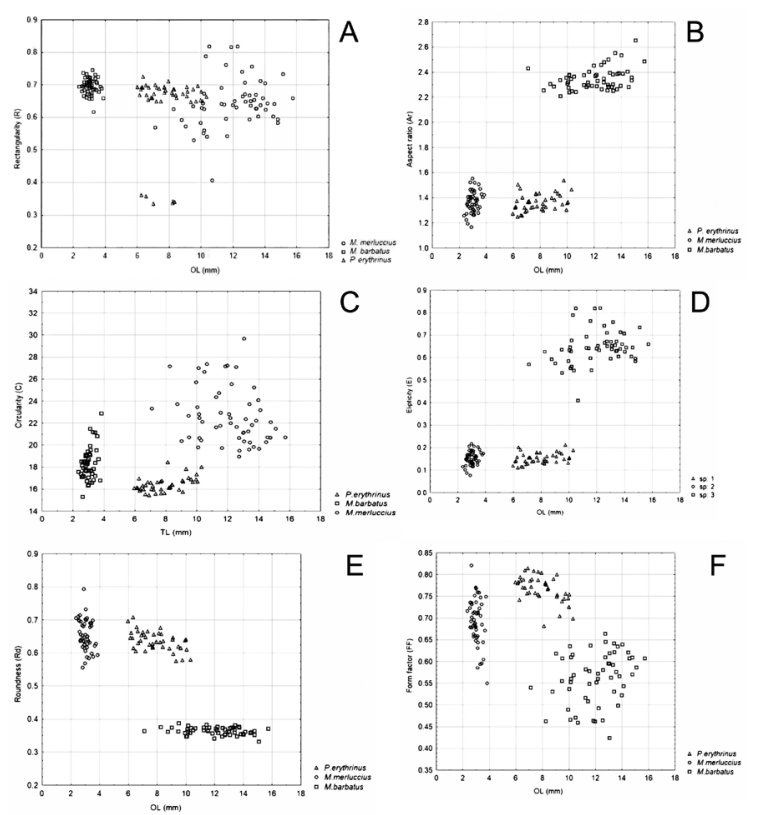

Fig. 3. Form factor (A), Roundness (B), Aspect ratio (C), Circularity (D), Rectangularity (E) and Elipticity (F) vs. maximal otolith length of tree demersal fish species

cies (Fig. 2). ANOVA showed that there were significant differences among shape indices of all analysed demersal fishes $(\mathrm{p}<0.05)$.

The values of shape indices showed correlation with otolith lengths for studied species, but the correlation values differed for different shape indices. Namely, when otoliths length increased, values of $\mathrm{R}_{\mathrm{D}}$ and $\mathrm{C}$ decreased, while $\mathrm{F}_{\mathrm{F}}, \mathrm{A}_{\mathrm{R}}, \mathrm{R}$ and $\mathrm{E}$ increased for the M. merluccius and P. erythrinus. For M. barbatus, when otolith length increased, $\mathrm{F}_{\mathrm{F}}, \mathrm{Rd}$ and $\mathrm{R}$ decreased, while $A_{R}, C$ and $E$ increased (Table 4, Fig. 3).

\section{DISCUSSION}

This study contributes to the understanding the morphological features of saggital otoliths of demersal fish species from Eastern Adriatic Sea. The present study analysed relationships between otolith length, height and weight and fish length using a linear function. The results obtained suggest there are no statistically significant differences between left and right otoliths for the studied fish species. When considering application of these results we have to emphasize that all future analyses would be standardized by using measurements from one selected otolith, left or right. The lack of statistically significant differences between left and right sagitta indicates that otoliths on either body side are equally usable for fish-size estimations (BATTAGLIA et al., 2010; MEHANNA et al., 2016; PARK et al., 2018; YILMAZ et al., 2015). Moreover, results of this study indicate there are no differences in relationships between otolith biometry and fish size between sexes. Contrary to these results, differences in otolith variables were observed between sexes for some species (VALLISNERI et al., 2008; BOSTANCI et al., 2012; KONTAS \& BOSTANCI, 2015).

There are many studies that determine the relationships between otolith biometry and fish sizes (PAXTON, 2000; ZORICA et al., 2010; JAWAD et al., 2012, DEHGHANI et al., 2015). For most species, the relationship between otolith length and fish length can be described by a simple linear regression (HARVEY, 2000). In present study, otolith length showed the strongest and otolith weight the weakest relationship to fish length in all three species. These results are consistent with literature data for demersal fish species 
from genera Symphodus and Coris (ŠKELJO \& FERRI, 2012). Contrary to this, results of the study of pelagic fish species indicate that the otolith weight could be a more accurate indicator of somatic growth (ZORICA et al., 2010).

Otolith development occurs under dual regulation: genetic conditions regulate the form of the otolith, while environmental conditions, mainly temperature, regulate the quantity of material deposited during the formation of the otolith (LOMBARTE \& LLEONART, 1993). In order to describe in detail the shape of the otoliths, six shape descriptors from scientific literature were used (TUSET et al., 2003; LORD et al., 2012). In addition to the shape analysis, otolith relative sizes were also estimated. Variation in size and shape of sagittal otoliths has long been used as taxonomic features (NAFPAKTITIS \& PAXTON, 1969). The variation in size of sagittal otoliths is significant and apparently correlated with taxonomic group, habitat, depth and luminescence (PAXTON, 2000; LOMBARTE \& CRUZ, 2007). Also, environmental abiotic factors, such as temperature and salinity, are also known to influence otolith shape (LOMBARTE \& LLEONART, 1993), and spatial variations in otolith shape are often interpreted as resulting from habitat differentiation (MORAT et al., 2012). However, such variation in abiotic factors is generally related to differences in prey categories available to an individual predator, such that geographical variations in diet composition could also generate geographical variations in otolith shape (VIGNON, 2012). The current study results show that shape indices have a different relationship pattern with maximum otolith length. More specifically, $R_{D}$, $A_{R}$ and $E$ show similar patterns in relations to maximum otolith length for all species, while $\mathrm{F}_{\mathrm{F}} \mathrm{C}$ and $\mathrm{R}$ show a different morphological pattern. Namely, when otolith lengths increased, the values of $\mathrm{F}_{\mathrm{F}}$ and $\mathrm{R}$ of $M$. barbatus decreased, while for M. merluccius and P. erythrinus these values increased. On the other hand, when $\mathrm{C}$ for $M$. barbatus increased, the values for $M$. merluccius and P. erythrinus decreased (Table 5, Fig. 3). Contrary to these results, the shape indices of the pelagic fish species show a similar pattern in relationship with maximum otolith length (ZORICA et al., 2010). The similarity in otolith shape descriptors may come from the fact that all studied pelagic fish species have similar ecological traits and occupy the same ecological niche (ZORICA et al., 2010). Obviously, difference in otolith shape reflects the characteristics of the individual habitat. GAULIDE \& CRAMPTON (2002) suggest that there is evident separation between most pelagic fish species and most deep-living species. LOMBARTE \& CRUZ (2007) found a relationship between otolith size composition, habitat and depth. The epipelagic community was characterized by species with very small otolith sizes, while in the demersal communities, the proportion of species with large sagittas increased with depth (LOMBARTE \& CRUZ, 2007). CAPPOCCIONI et al. (2011) reported the occurrence of changes in the morphology of the European eel (Anguilla anguilla) otoliths as a function of growth and the different habitat ecology (a river and two brackish water lagoons). Also, the shape outline of otoliths changes during ontogenesis, along with the increase in animal size (CAPPOCCIONI et al., 2011).

There is a clear relationship between taxonomic groups and otolith relative size (NOLF, 1985). Also, numerous endogenous factors can influence the otolith relative size, such as phylogeny (GAEMERS 1984; NOLF 1985), adaptive aspects related with the inner ear functions (PAXTON 2000; PARMENTIER et al., 2001), or specialization in acoustic communication (LOMBARTE \& CRUZ, 2007). In this study two species from order Perciformes (M. barbatus and P.erythrinus) and $M$. merlucius from Order Gadiformes were studied. The results of otolith relative size analysis show that sagittas of M. merluccius and $P$. erythrinus can be classified as Large $\left(\mathrm{O}_{\mathrm{R}}\right.$ $=0.73$ and $\mathrm{O}_{\mathrm{R}}=0.82$ respectively) while sagittal otoliths of $M$. barbatus could be considered Small $\left(\mathrm{O}_{\mathrm{R}}=0.21\right)$. Some taxonomic group like Gadiformes tend to have medium or large sagittae, while Perciformes, with their great ecological and morphological variability, exhibit a wide range of otolith sizes (LOMBARTE \& CRUZ, 2007). These results also agreed with previously reported large-sized otoliths for $P$. erythrinus and small for $M$. barbatus (LOMBARTE \& CRUZ, 
Table 4. Descriptive statistics of six shape indices ( $F_{F}$-form factor, $R_{D}$-roundness, $A_{R^{-}}$aspect ratio, $C$-circularity, $R-$ rectangularity, E-elipticity) of three demersal fish species from Montenegro. Shown is otolith relative size- $O_{R}$, size category in relation to $O_{R}\left(S\right.$-small, L-large) also $\left(C_{o}\right)$

\begin{tabular}{lllllllll}
\hline Species & $\mathrm{F}_{\mathrm{F}}$ & $\mathrm{R}_{\mathrm{D}}$ & $\mathrm{A}_{\mathrm{R}}$ & $\mathrm{C}$ & $\mathrm{R}$ & $\mathrm{E}$ & $\mathrm{O}_{\mathrm{R}}$ & $\mathrm{C}_{0}$ \\
\hline $\begin{array}{l}\text { Merluccius } \\
\text { merluccius }\end{array}$ & $0.56 \pm 0.06$ & $0.36 \pm 0.01$ & $2.35 \pm 0.09$ & $22.63 \pm 2.54$ & $0.64 \pm 0.08$ & $0.40 \pm 0.02$ & 0.73 & $\mathrm{~L}$ \\
$\begin{array}{l}\text { Mullus } \\
\text { barbatus }\end{array}$ & $0.69 \pm 0.06$ & $0.65 \pm 0.05$ & $1.35 \pm 0.10$ & $18.43 \pm 1.89$ & $0.68 \pm 0.02$ & $0.15 \pm 0.04$ & 0.21 & $\mathrm{~S}$ \\
$\begin{array}{l}\text { Pagellus } \\
\text { erythrinus }\end{array}$ & $0.71 \pm 0.13$ & $0.59 \pm 0.11$ & $1.36 \pm 0.06$ & $18.63 \pm 1.12$ & $0.63 \pm 0.11$ & $0.15 \pm 0.02$ & 0.84 & $\mathrm{~L}$ \\
\hline
\end{tabular}

Table 5. Coefficient of correlation ( $r$ ) between the maximum length of fish otolith and shape indices ( $F_{F}$-form factor, $R_{D^{-}}$roundness, $A_{R}$-aspect ratio, $C$-circularity, $R$ - rectangularity, E-elipticity) of three demersal fish species from Montenegro

\begin{tabular}{lllllll}
\hline Species & $\mathrm{F}_{\mathrm{F}}$ & $\mathrm{R}_{\mathrm{D}}$ & $\mathrm{A}_{\mathrm{R}}$ & $\mathrm{C}$ & $\mathrm{R}$ & $\mathrm{E}$ \\
\hline $\begin{array}{l}\text { Merluccius } \\
\text { merllucius }\end{array}$ & $0.2804 *$ & -0.2275 & $0.3590^{* *}$ & $-0.2692^{*}$ & 0.236 & $0.356^{*}$ \\
$\begin{array}{l}\text { Mullus barbatus } \\
\begin{array}{l}\text { Pagellus } \\
\text { erythrinus }\end{array}\end{array}$ & $-0.4577^{* *}$ & $-0.5020^{* * *}$ & $0.3527^{*}$ & $0.4694^{* *}$ & $-0.3945^{* *}$ & $0.3403^{*}$ \\
\hline
\end{tabular}

2007). However, it should be emphasized that the values of the relative size of otoliths of $P$. erythrinus and $M$. barbatus from Adriatic Sea were higher than in the research of LOMBARTE \& CRUZ (2007) $\left(\mathrm{O}_{\mathrm{R}}=0.69\right.$ and $\mathrm{O}_{\mathrm{R}}=0.16$, respectively). On the other hand, large otoliths of $M$. merluccius are in contrast with reported medium otoliths $\left(\mathrm{O}_{\mathrm{R}}=0.53\right)$ for hake from north-western Mediterranean Sea (Balearic Sea) (LOMBARTE \& CRUZ, 2007). The same authors suggested that the importance of acoustic communications is correlated with a moderate to large otolith size in a benthic environment in order to compensate for the reduction of light with depth. Closely related species or populations from temperate or shallower waters have relatively larger otoliths than those from colder or deeper water (GAULDIE 1993; TORRES et al., 2000).

In summary, this study demonstrated the variation in the size and shape of sagittal otoliths of demersal fish and confirmed its potential as a powerful tool for fish identifications and fish size estimation, important factors in fish stock monitoring and management. In addition, different patterns of otolith shape descriptors imply that morphology variations were correlated with ecological and environmental variations in depth and substrate type more than phylogenetics relationships. It is suggested that future studies should concentrate on the relationship between otolith shape and size with environmental factors.

\section{REFERENCES}

AGUiRRE, H. \& A. LOMBARTE. 1999. Ecomorphological comparisons of sagittae in Mullus barbatus and M. surmuletus. J. Fish Biol. 55: 105-114. DOI: https://doi. org/10.1111/j.1095-8649.1999.tb00660.x

BElCHIER, M., C. ClEMMESEN, D. CORTES, T. DOAN \& A. FOLKVORD. 2004. Recruitment studies: Manual on precision and accuracy of tools. ICES Techniques in Marine Environmental Sciences 35: 35pp. DOI: http://dx.doi. org/10.25607/OBP-23

BATTAGlia, P., D. MALARA, T. ROMEO \& F. ANDOLARO. 2010. Relationship between otolith size and fish size in some mesopelagic and bathypelagic species from the Mediterranean Sea (Strait of Messina, Italy). Sci- 
entia Marina 74: 605-612. DOI: 10.3989/ scimar.2010.74n3605

BOLLES, K.L. \& A.G. BEGG. 2000. Distinctions between silver hake (Merluccius bilinearis) stocks in U.S. waters of the northwest Atlantic based on whole otolith morphometric. Fish Bulletin 98: 451-462.

BOSTANCI, D, S., YILMAZ, N. POLAT \& S. KONTAS 2012. The otolith biometry characteristics of black scorpion fish, Scorpaena porcus L., 1758. The Black Sea J. Sci 2: 59-68.

BOSTANCI, D., N. POLAT N, G. KURUCU, S. YEDIER, S. KONTAS \& M. DARCIN. 2015. Using otolith shape and morphometry to identify four Alburnus species (A. chalcoides, A. escherichii, A. mossulensis and A. tarichi) in Turkish inland waters. J. Appl. Ichthyol. 31(6): 1013-1022. DOI: 10.1111/jai.12860.

CARBONARA, P., S., INTINI, J., KOLITARI, A JOKSIMOVIĆ, N. MILONE, G. LEMBO, L. CASCIARO, I. BITETTO, W: ZUPA, M.T. SPEDICATO \& L. SION. 2018. A holistic approach to the age validation of Mullus barbatus L., 1758 in the Southern Adriatic Sea (Central Mediterranean). Sci. Rep. 8: 13219. DOI: https://doi. org/10.1038/s41598-018-30872-1

CARDINALE, M., P. DOERING-ARJES, M. KASTOWSKY \& H. MOSEGAARD. 2004. Effects of sex, stock, and environment on the shape of known-age Atlantic cod (Gadus morhua) otoliths. Can. J. Fish. Aquat. Sci. 61: 158167. DOI: $10.1139 /$ f03-151

CAPOCCIONI, F., C. COSTA, J. AGUZZI, P. MENESATTI, A. LOMBARTE \& E. CICCOTI. 2011. Ontogenetic and environmental effects on otolith shape variability in three Mediterranean European eel (Anguilla anguilla, L.) local stocks. J. Exp. Mar. Biol. Ecol. 397(1): 1-7. DOI: 10.1016/j.jembe.2010.11.011.

DEHGHANI, M., E. KAMRANI, A. SALARPOUR \& E. KAMALI. 2015. Relationship Between Fish Length and Otolith Dimensions (Length, Width) and Otolith Weight of Sardinella sindensis, as Index for Environmental Studies, Persian Gulf, Iran. Journal of Fisheries and Livestock Production 3:2. DOI: 10.4172/23322608.1000134

DULČIĆ, J. \& M. KRALJEVIĆ. 1996. Weight-length relationships for 40 fish species in the east- ern Adriatic (Croatian waters). Fisheries Research, Volume 28, Issue 3: 243-251. DOI: https://doi.org/10.1016/0165-7836(96)00513-9.

DULČIĆ, J. \& B., GLAMUZINA. 2006. Lengthweight relationships for selected fish species from three eastern Adriatic estuarine systems (Croatia). Journal of Applied Ichthyology, 22: 254-256. DOI: https://doi.org/10.1111/ j.1439-0426.2006.00633.x

FERRI, J., K. BARTULIN \& F. ŠKELJO. 2018. Variability of Otolith Morphology and Morphometry in Eight Juvenile Fish Species in the Coastal Eastern Adriatic. Croatian Journal of Fisheries 76(3):91-98. DOI: 10.2478/cjf2018-0012.

GAULDIE, R. W. 1993. Continuous and discontinuous growth in the otolith of Macruronus novaezelandiae (Merlucciidae: Teleostei). J. Morphol. 216: 271-294.

GAULDIE, R. W. \& J. S. CRAMPTON. 2002. An eco-morphological explanation of individual variability in the shape of the fish otolith: comparison of the otolith of Hoplostethus atlanticus with other species by depth. J. Fish. Biol. 60: 1204-1221. https://doi. org/10.1111/j.1095-8649.2002.tb01715.x

GFCM 2018. GFCM Data Collection Reference Framework (DCRF). Version: 20.1.

HARVEY, J. T., R.T. LOUGHLIN, A. M. PEREZ \& S.D. OXMAN. 2000. Relationship between fish size and otolith length for 63 species of fishes from the eastern North Pacific Ocean. NOAA/National Marine Fisheries Service, (NOAA Technical Report NMFS, 150).

HUESSY, K. 2008. Otolith shape in juvenile cod (Gadus morhua): Ontogenetic and environmental effects. J. Exp. Mar. Biol. Ecol. 364(1):35-41. DOI: 10.1016/j. jembe.2008.06.026.

IKICA, Z., M. DJUROVIĆ, A. JOKSIMOVIĆ, M. MANDIĆ, O. MARKOVIĆ, A. PEŠIĆ, E. ARNERI, L. CERIOLA \& N. MILONE. 2018. Monitoring of the Montenegrin Fisheries Sector: Biological Sampling (September 2007 - August 2011). Stud. Mar. Monograph Series 1. ISBN: 9789940-9613-1-2.

JAWAD, L, Z., SADIGHZADEH \& H. AL-BUSAIDI. 2012. The relationship between fish length 
and otolith dimension of mugilid fish, Liza kluzingeri (Day, 1988) collected from the Persian gulf near Bandar Abbas. Ann. Ser. Hist. Nat. 22: 77-82.

JOKSIMOVIĆ, A. 1999. Length-weight relationship of pandora, Pagellus erythrinus (Linnaeus, 1758), from the Montenegrin shelf. Acta Biologica Iugoslavica- Ichthyologia, 31(1): 9-21.

JOKSIMOVIĆ, A. 2000. Biomass estimate and maximum sustainable yield of Pandora Pagellus erythrinus (Linnaeus, 1758) in trawling fisheries at Montenegrin shelf. Acta Biologica Iugoslavica-Ichthyologia 32 (1): 17-29.

JOKSIMOVIĆ, A. 2001. Growth of pandora, Pagellus erythrinus in Montenegrin shelf (South Adriatic). In: $36^{\text {th }}$ Congress Commision Internationale pour l'ExplorationScientifique de la merMediterranee, CIESM, 24-28 Septembre 2001, Monte-Carlo. Conference proceedings: 278.

JOKSIMOVIĆ, A. 2004. Mortality of pandora, Pagellus erythrinus in Montenegrin shelf (South Adriatic). In: $37^{\text {th }}$ Congress Commision Internationale pour 1'ExplorationScientifique de la merMediterranee, CIESM, 7-11 June 2004, Barcelona. Conference proceedings: 374.

JOKSIMOVIĆ, A., S. REGNER \& O. KASALICA. 2007. Length-wight relationship of Red mullet, Mullus barbatus (L. 1758) in trawl fisheries on the Montenegrian coast. In: III International Conference »Fishery«, 1-3 February 2007, Zemun-Belgrade. Conference proceedings: pp. 353-358.

JOKSIMOVIĆ, A., S. REGNER, O. KASALICA, M. ĐUROVIĆ, A. PEŠIĆ \& M. MANDIĆ. 2008. Growth of the Red Mullet, Mullus barbatus, Linneaus, 1758 on the Montenegrin shelf (South Adriatic). Electron J. Ichthyol (EJI) 4(1): 1-7. ISSN: 1565-7396.

JOKSIMOVIĆ, A., A. PEŠIĆ, M. ĐUROVIĆ, Z. IKICA, O. MARKOVIĆ \& M. MANDIĆ. 2019. The state of marine fisheries in Montenegro in the last 15 years. Stud. Mar. 33(2): 12-22. ISSN: 0585-5349.

KONTAS, S. \& D. BOSTANCI. 2015. Morphological and biometrical characteristics on otolith of Barbus tauricus Kessler, 1877 on light and scanning electron microscope. Int. J. Morphol. 33 (4): 1380-1385. http://dx.doi. org/10.4067/S0717-95022015000400032

LOMBARTE, A. \& A. CRUZ. 2007. Otolith size trends in marine com-munities from different depth strata. J. Fish Biol. 71 (1): 53-76. DOI: 10.1111/j.1095-8649.2007.01465.x.

LOMBARTE, A. \& J. LLEONART. 1993. Otolith size changes related with body growth, habitat depth and temperature. Environ. Biol. Fishes 37 (3): 297-306.

LORD, C., L. MORAT, R. LECOMTE-FINIGER \& P. KEITH. 2012. Otolith shape analysis for three Siciopterus (Teleostei: Gobioidei: Sciaenidae) species from New Caledonia and Vanuatu. Environ. Biol. Fishes. 93 (2): 209-222.

MANDIĆ, M., A. PEŠIĆ, A. JOKSIMOVIĆ \& M. ĐUROVIĆ. 2008. Main characteristic of Population Dynamic of Hake (Merluccius merluccius, Linnaeus 1758) in the Open Sea of the Montenegrin coastal waters. Natura Montenegrina 7(3): 529-536.

MEHANNA, S. F., A. L. JAWAD, Y. A. AHMED, M. A. ABU EL-REGAL \& D. DAWOOD. 2016. Relationships between fish size and otolith measurements for Chlorurus sordidus (Forsskal, 1775) and Hipposcarus harid (Forsskal, 1775) from the Red Sea coast of Egypt. J. Appl. Ichthyol. 32: 356-358. doi: 10.1111/ jai.12995

MERIGOT, B., Y. LETOURNEUR Y. \& R. LECOMTEFINIGER. 2007. Characterization of local populations of the common sole Solea solea (Pisces Soleidae) in the NW Mediterranean through otolith morphometrics and shape analysis. Mar. Biol. 151 (3): 997-1008. DOI: 10.1007/s00227-006-0549-0.

MORAT, F., D. BANARU, B. MERIGOT, E.I. BATJAKAS, S. BETOULLE, M. VIGNON, R. LECOMTEFINIGER \& Y. LETOURNEUR. 2007. Relationships between fish length and otolith length for nine teleost fish species from the Mediterranean basin, Kerguelen Islands and Pacific Ocean. Cybium 32 (3): 265-269.

MILle, T., K. MAHE K, M. CACHERA, C. M. VILLANUEVA, H DE PONTUAL \& B. ERNARDE. 2016. Diet is correlated with otolith shape 
in marine fish. Mar. Ecol. Prog. Ser. 555 167-184. DOI: https://doi.org/10.3354/ meps 11784

MINISTRY OF AGRICULTURE AND RURAL DEVELOPMENT. 2020. Annual Montenegro fishery data collection programme (DCF-DCRF), Podgorica.

NAFPAKTITIS, B. G. \& R. J. PAXTON. 1969. Review of the lanternfish genus Lampadena with a description of a new species. LA Co.Mus. Nat. His. Contrib. Sci., 138: 1-29.

NOLF, D. 1985. Otolith piscium. In: Schultze H. P. (Edsitors) Handbook of Paleoichthyology, Vol. 10 Gustav Fisher Verlag, Sttutgart., Pp. $1-145$.

OZPICAK, M., S. SAYGIN, A. AYKUT AYDIN, E. HANCER, S. SAVAŞYILMAZ \& N. POLAT. 2018. Otolith shape analyses of Squalius cephalus (Linnaeus, 1758) (Actinopterygii: Cyprinidae) inhabiting four inland water bodies of the middle Black Sea region, Turkey. Iran. J. Ichthyol. 5 (4): 293-302. DOI: 10.22034/ iji.v5i4.311

PAXTON, R. J. 2000. Fish otolith: do sizes correlate with taxonomic group, habitat and/or luminiscence? The Royal society 355: 12991303. doi: $10.1098 /$ rstb. 2000.0688

PARK, J.M., F. T. GASTON, R. RIEDEL \& E.J. WILLIAMSON. 2018. Biometric relationships between body and otolith measurements in nine demersal fishes from north-eastern Tasmanian waters, Australia. J. Appl. Ichthyol. 34: 801-805. https://doi.org/10.1111/ jai.13612

PARMENTIER, E., P. VANDEWALLE \& F. LAGARDE. 2001. Morpho-anatomy of the otic region in carapid fishes: eco-morphological study of their otoliths. J. Fish Biol. 58: 10461061. https://doi.org/10.1111/j.1095-8649.2001. tb00554.x

PEŠIĆ, A., A. JOKSIMOVIĆ, S. REGNER. \& B. MIĆKOVIĆ. 2011. Some biological parameters of red mullet, Mullus barbatus (Linnaeus, 1758), in Montenegrin waters. Stud. Mar. 25 (1): 121-136.

PICCINETTI, C., N. VRGOČ, B. MARČETA \& C. MANFREDI. 2012. Recent state of demersal resources in the Adriatic Sea. Acta Adriat., Monograph Ser. No. 5, 220 p.

REICHENBACHER, B., E. KAMRANI, R.H. ESMAEILI \& A. TEIMORI. 2009. The endangered cyprinodont Aphanius ginaonis (Holly, 1929) from southern Iran is a valid species: evidence from otolith morphology. Environ. Biol. Fishes. 86 (4): 507-521. DOI: 10.1007/ s10641-009-9549-5.

STATISTICAL OFFICE OF MONTENEGRO - MONSTAT. 2019. Statistical Yearbook 2019. Statistical Office of Montenegro - MONSTAT, Podgorica.

ŠKELJO, F. \& J. FERRI. 2012. The use of otolith shape and morphometry for identification and size-estimation of five wrasse species in predator prey studies. J. App. Ichtyol. 28 (4): 524-530. https://doi.org/10.1111/j.14390426.2011.01925.x

TEŠIĆ, M. 1962. About the greatest depths of the Adriatic Sea. Hidrografski godisnjak: 129139.

TORRES, G. J., A. LOMBARTE \& B. MORALES-NIN. 2000. Variability of the sulcus acusticus in the sagitta otolith of the genus Merluccius. Fish. Res. 46: 5-13. DOI: 10.1016/S01657836(00)00128-4

TUSET, V. M., A. LOMBARTE, A. J. GONZALES, F.J. PERTUSA \& J.M. LORENTE. 2003. Comparative morphology of saggital otolith in Seranus spp. J. Fish Biol. 63 (6): 1491-1504. https:// doi.org/10.1111/j.1095-8649.2003.00262.x

UNEP-MAP-RAC/SPA. 2015. Adriatic Sea: Status and conservation of fisheries. By Farrugio, H. \&Soldo, A. Edited by Cebrian, D. and Requena, S., RAC/SPA, Tunis, 58 pp.

ZHUANG, L., Y. YE ZHENJIANG \& C. ZHANG. 2014. Applications of otolith shape analysis to species separation in Sebastes spp. from the Bohai Sea and the Yellow Sea, northwest Pacific. Env. Biol. Fishes. 98 (2): 547-558. DOI: $10.1007 / \mathrm{s} 10641-014-0286-\mathrm{z}$.

ZORICA, B., G. SINOVČIĆ \& V. ČIKEŠ KEČ. 2010. Preliminary data on the study of otolith morphology of five pelagic fish species from the Adriatic Sea (Croatia). Acta Adriat., 51: 89-96.

ZORICA, B., V. ČIKEŠ KEČ, N. VRGOČ, I. ISAJLOVIĆ, C. PICCINETTI, M. MANDIĆ, B. MARČETA \& A. 
PEŠIĆ. 2020. A review of reproduction biology and spawning/ nursery grounds of the most important Adriatic commercial fish species in the last two decades. Acta Adriat., 61 (1):89-100

YILMAZ, S., O. YAZICIOGLU, S. SAYGIN (AYAYDIN) \& N. POLAT. 2015. Relationships of otolith dimension with body length of European Perch, Perca fluviatilis L., 1758 from Lake Ladik, Turkey. Pak. J. Zool. 46 (5): 12311238.

VALLISNERI, M., V. TROTTA, S. CAVICCHI \& C. PICCINETTI. 2008. Sex specific somatic-otolith growth relationship in two Gadidae. J. Fish Biol. 72: 724-730. https://doi.org/10.1111/ j.1095-8649.2007.01708.x

VIGNON, M. 2012. Ontogenetic trajectories of otolith shape during shift in habi- tat use:interaction between otolith growth and environment. J. Exp. Mar. Biol. Ecol. 420-421: 26-32.

VRGOČ, N., M. PEHARDA ULJEVIĆ, \& S. KRSTULOVIĆ ŠIFNER. 2005. Assessment of demersal fish and shellfish stocks commercially exploited in Croatia. PHARE 2005 Project: EuropeAid/123624/D/SER/HR, Final output, p. 172.

VRGOČ, N., E. ARNERI, S. JUKIĆ-PELADIĆ, S. KRSTULOVIĆ ŠIFNER, P. MANNINI, B. MARČETA, K. OSMANI, C. PICCINETTI \& N. UNGARO. 2004. Review of current knowledge on shared demersal stocks of the Adriatic Sea. FAO-MiPAF Scientific Cooperation to Support Responsible Fisheries in the Adriatic Sea. GPC/REP//ITA/TD-12. AdriaMed The. Doc., 12: $91 \mathrm{pp}$. 


\title{
Odnos dužine i maksimalnog obujma za 24 riblje vrste u sjevernom Egejskom moru (istočno Sredozemno more)
}

\author{
Angeliki ADAMIDOU*, Konstantinos TOULOUMIS i \\ Athanassios C. TSIKLIRAS
}

\begin{abstract}
SAŽETAK
Poznavanje morfoloških odnosa, a posebno onih koji se tiču maksimalnog obujma tijela ribe (G) s ukupnom dužinom (TL) potrebito je za određivanje selektivnosti alata, a posebno za tehničke mjere za izbjegavanje hvatanja nedoraslih jedinki. Ova studija se odnosi na 24 morske vrste koje se iskorištavaju u priobalnoj ribolovnoj floti u Egejskom moru (istočno Sredozemno more), za 6 od kojih se TL-G odnosi prvi put spominju u Sredozemnom moru i susjednim morima.

Uzorci su prikupljani sezonski, od travnja 2016. do veljače 2017. Koeficijenti linearne regresije obujma tijela u tri položaja tijela $\left(G_{\text {eye }}\right.$, posteriorno od oka; $G_{\text {head }}$ na stražnjem kraju operkuluma; $\mathrm{G}_{\max }$ na maksimalnoj visini tijela), $\mathrm{s}$ ukupnom duljinom procijenjene su za svaku vrstu i za skupine oblikovane kada su $G_{\text {eye }}, G_{\text {head }}$ i $G_{\text {max }}$ ucrtani u odnosu na ukupnu duljinu za sve vrste zajedno.

Utvrđene su statistički značajne razlike između tri skupine (ANCOVA, $\mathrm{P}<0,001$ ). Usporedba odnosa ukupne duljine i obujma tijela za 18 vrsta koje su prethodno istraživane u različitim geografskim područjima Sredozemlja i susjednih mora, pokazala je razlike uglavnom s rezultatima iz portugalskih voda za određene populacije vrsta. Na temelju dobivenih jednadžbi izračunat je maksimalni obujam $\left(\mathrm{G}_{\max }\right)$ koji odgovara minimalnoj referentnoj veličini očuvanja (MCRS) i ukupnoj dužini pri zrelosti $(\mathrm{Lm})$ za svaku vrstu. Identificirane veličine oka koje odgovaraju $\mathrm{G}_{\max }$ vrijednostima bile su dosta veće od minimalne zakonske veličine oka za mreže stajačice i unutarnju ploču troslojnih mreža, što ukazuje da relevantni trenutačni propisi o ribarstvu ne mogu ispuniti zahtjeve za održivo iskorištavanje ribljih resursa.
\end{abstract}

Ključne riječi: morfologija ribe; upravljanje ribarstvom; mreža stajačica; duljina pri zrelosti $\left(\mathrm{L}_{\mathrm{m}}\right)$; Minimalna referentna veličina očuvanja (MCRS); trostruka mreža stajačica 